\title{
日本における医薬品経済評価の現状
}

濱島ちさと*, 池田俊也*, 池上直己*

\section{Critical Appraisal of Pharmacoeconomic Studies in Japan}

\author{
Chisato HAMASHIMA*, Syunya IKEDA*, Naomi IKEGAMI* \\ * Department of Health Policy and Management Keio University School of Medicine \\ 35 Shinanomachi, Shinjuku-ku, Tokyo 160, Japan
}

\begin{abstract}
〈Abstract〉
Objective : The economic aspect of pharmaceuticals is becoming a major issue of health care financing in Japan due to the high total volume of drug consumption. To consider the feasibility and usefulness of pharmacoeconomic (PE) studies in health policy making, we aimed to conduct a review of $\mathrm{PE}$ studies published in Japan.

Methods: We collected original published PE studies conducted in Japan from 1985 to 1995, by retrieving through computer databases such as MEDLINE and JMEDICINE, as well as other methods. We then reviewed the papers according to a checklist developed by Drummond et al.

Results : Fourteen articles were found to satisfy the inclusion criteria. The overall checklist compliance rate were $45.8 \%$. All of the PE studies were based on randomized clinical trial. Most of the studies lacked some important elements of $\mathrm{PE}$ analysis, such as the identification of all important and relevant costs and consequences (14.3\%) and the presentation of all issues of concern (7.1\%). Furthermore, most models and assumptions used in the studies were considered by us to be unreliable and inappropriate.

Discussion : The quality of PE studies conducted in Japan was not considered by us to be satisfactory and our analysis identified areas for improvement. Further improvement in this field is urgently needed and may be achieved through PE guideline development and the training of specialists.
\end{abstract}

Key words : pharmacoeconomic studies, new drug, pharmacoeconomic guidelines, critical appraisal

\begin{abstract}
緒 論
先進諸国では医療費の高騰が国家財政を圧迫す る要因の一つとなり,さまざまな医療費抑制策が 導入されている。このため, 医薬品をめぐる政策 決定においても経済評価の利用が進められてい る1).

わが国でも，近年，医療費増加が社会的に問題 となり，医療保険制度のさまざまな側面の見直し が求められつつある。 とくに国民医療費に占める
\end{abstract}

薬剤比率が約 $30 \%$ と諸外国に比し高率であるこ とはしばしば問題とされてきた。こうしたなかで, 1992 年 8 月より, 新薬の薬価基準申請時に医療経 済評価資料の提出が認められるようになり, 製薬 企業における経済評価の取組みが活発になってき ている3．そこで, 我々は, これまでわが国で公表 された医薬品の経済評価研究の批判的吟味を行 い, 研究の現状の問題点と今後の課題について検 討した。

* 慶應義塾大学医学部医療政策・管理学 $\quad$ 个 160 東京都新宿区信濃町 35 


\section{方 法}

\section{1. 対象文献の抽出}

1985 年から 1995 年の 11 年間に, 新薬開発に際 して行われた医薬品経済評価の公表論文を対象と した。ただし，剤型変更に伴う追加品目や適応の 拡大に伴い，厚生省への資料提出に関連して行わ れたと考えられる文献も検討対象に加えた。

文献の抽出は医学中央雑誌, JMEDLINE, MEDLINE, HEALTH, およびすでに発表された 経済評価のレビュー4,5)に基づき収集した。この 際，総説，学会発表抄録やニューズレターなどは 除外し，原著論文のみを対象とした。

経済評価の方法としては, 複数の代替可能な治 療や診断技術（以下，代替案）と比較のうえで, 費用と効果をともに検討した費用最小化分析 (CMA：cost-minimization analysis), 費用・効 果分析 (CEA： cost-effectiveness analysis), 費 用 - 効用分析 (CUA：cost-utility analysis), 費 用・便益分析 (CBA：cost-benefit analysis) が理 想的な方法である ${ }^{6}$. 費用分析 (CA：cost analysis）は費用のみの検討ではあるが, 複数の代替案 と比較のうえで行われることから今回の検討対象 に加えた。この観点から研究目的や方法を再確認 し，上記の方法に限定した.

\section{2. チェックリストによる文献評価}

1.で抽出された文献のレビューを行い, 同一 の視点からの評価を行った。レビューは共著者 2 名が各々独立して行い, 各自の結果に基づいて討 論を重ね, 再検討した。

経済評価研究の結果の批判的吟味にはいくつか の評価基準が開発されている ${ }^{629}$. 評価項目の詳細 は異なるが，経済評価研究に必須となる対象とな る治療や診断技術の結果と費用の記述を始めとす る項目が含まれている。今回は，わが国でも広く 用いられているDrummond の 10 項目の チェックリスト(以下，チェックリスト) ${ }^{6,9)}$ を基本 的な評価基準として用いた（Table 1).

評価は，チェックリストを完全に満足するもの は○，不完全ながら満足するものは $\triangle$, 満足しな いものには×の 3 段階で行った。 チェックリスト
の 1 から 10 の大項目の中の小項目を参照しなが ら，小項目をすべて満たしたうえで，大項目に完 全に満足する場合は $\bigcirc ， 一$ 部の小項目を満たさな い場合は $\triangle$, 大項目・小項目ともに満たさない場 合を×として判定を行った. しかし分析の手法に よってはチェックリストの項目が評価の対象とな らないこともあり,この場合はーとした。

さらに対象文献の研究内容を明確にするため に，チェックリストの以下の項目については具体 的内容を付記し検討した。すなわち，(1)対象薬， (2)対象疾患, (3)比較対照, (4)分析方法, (5)分析の 立場（viewpoint），(6)分析に用いたモデル，(7)費 用(直接費用か間接費用か), 8)効果あるいは便益, (9)時間範囲 (time horizon), (10割引率の 10 項目 である。

\section{結 果}

\section{1. 対象文献の抽出}

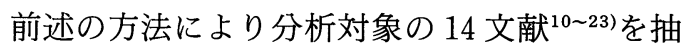
出し, 発表年次順に Table 2 に示した.

\section{2. チェックリストによる文献評価}

Table 1のチェックリストによる評価結果を Table 3 に示した. さらに対象文献の具体的内容 については Table 4 に示し, チェックリストの項 目とあわせて検討した。

チェックリストの適応率は，完全なもの（○）

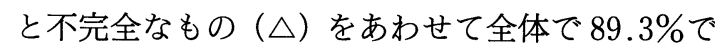
あった．また完全なもの（○）に限定した場合は， 適応率は $45.8 \%$ であった。

各項目の評価の詳細は以下のとおりである，適 応率として示したのは，完全なもの（○）と不完 全なもの（ $\triangle ）$ が含まれた，ゆるやかな基準によ るものである。次に（）つきで示した割合は, 厳密な基準，すなわち完全なもの（○）に限定し た結果である。

1 ）明確に定義した問題を回答可能な形で提出 しているか.

適応率：85.7\%（14.3\%）

経済評価を行うべき問題については 14 文献す べてに示されていた（チェックリスト1.1，以下 チェックリスト番号のみ記載).またいずれも他の 
Table 1 Checklist for assessing economic evaluations (Drummond et al. 1987)

1. Was a well-defined question posed in answerable form?

1.1 Did the study examine both costs and effects of the service(s) or programme(s) ?

1.2 Did the study involve a comparison of alternatives?

1.3 Was a viewpoints for the analysis stated and was the study placed in any particular decision-making context?

2. Was a comprehensive description of the competing alternatives given?

2.1 Were any inportant alternatives omitted?

2.2 Was (Should) a do-nothing alternative (be) considered?

3 . Was there evidence that the programmes' effectiveness had been established?

3.1 Has this been done through a randomized controlled clinical trial? If not, how strong was the evidence of effectiveness?

4. Were all the important and relevant costs and consequences for each alternative identified?

4.1 Was the range wide enough for the research quention at hand?

4.2 Did it cover all relevant viewpoints?

4.3 Were capital costs, as well as operating costs, included?

5 . Were costs and consequences measured accurately in appropriate physical units?

5.1 Were any of the identified items omitted from measurement?

5.2 Were there any special circumstance that made measurement difficult?

Were theses circumstances handled appropriately?

6 . Were costs and consequences valued credibly?

6.1 Were the sources of all values clearly identified?

6.2 Were market values employed for changes involving resources gained or depleted?

6.3 Where market values were adsent, or market, values did not reflect actual values, were adjustment made to approximate market values?

6.4 Was the valuation of consequences appropriate for the question posed?

7. Were costs and consequences adjusted for differential timing ?

7.1 Were costs and consequences which occur in the future "discounted" to their present values?

7.2 Was any justifications given for the discount rate used?

8. Was an incremental analysis of costs and consequences of alternatives performed?

8.1 Were the additional (incremental) costs generated by one alternatives over another compared to the additional effects, benefits or utilities generated?

9 . Was a sensitivity analysis performed?

9.1 Was justification provided for the range of values employed in the sensitivity analysis?

9.2 Were study results sensitive to changes in values?

10. Did the presentation and discussion of study results include all issues of concern to users?

10.1 Were the conclusions of the analysis based on some overall index or ratio of costs to consequences? If so, was the index interpreted intelligently or in a mechanistic fashion?

10.2 Were the results compared with those of others who have investigated the same question?

10.3 Did the study discuss the generalizabolity of the results to other settings and patients/clients groups?

10.4 Did the study allude to, or take account of, other important factors in the choice or decision under consideration?

代替案との比較のうえでの検討が行われていた (1.2).ただし費用分析の 1 文献は, 効果について の検討はなく，経済評価の方法としては部分的な ものである.

対象文献中，分析の立場を明確にした（1.3）の
は 2 文献のみであり, 各々，支払い者の立場と社 会の立場であった

2 ) 代替案を包括的に記述しているか.

適応率：100\%（57.1\%）

代替案は対象文献のすべてで示されていた 
Table 2 Pharmacoeconomics studies of selected for review

\begin{tabular}{|c|c|c|c|c|}
\hline No. & Year & Author & Journal & Reference \\
\hline 1 & 1985 & $\begin{array}{l}\text { Fujino } \\
\text { et al. }\end{array}$ & Health Policy & $\begin{array}{l}\text { Cost-benefit analysis of medical treatment of gastric } \\
\text { ulcers. Long-term model including healing and reoc- } \\
\text { currence }\end{array}$ \\
\hline 2 & 1988 & $\begin{array}{l}\text { Fujino } \\
\text { et al. }\end{array}$ & $\begin{array}{l}\text { Japanese Pharmacology \& } \\
\text { Therapeutics }\end{array}$ & $\begin{array}{l}\text { The cost/benefits analysis of TTS nitroglycerin-Tech- } \\
\text { nology assessment model of new drug delivery system- }\end{array}$ \\
\hline 3 & 1989 & $\begin{array}{l}\text { Fujino } \\
\text { et al. }\end{array}$ & $\begin{array}{l}\text { Journal of Clinical } \\
\text { Thereapeutics \& Medicines }\end{array}$ & $\begin{array}{l}\text { Cost-effectiveness analysis of antihyperlipidemic therapy } \\
\text { in the prevention of coronary heart disease-The case of } \\
\text { pravastatin (A HMG-COA reductase inhibitor) - }\end{array}$ \\
\hline 4 & 1992 & $\begin{array}{l}\text { Fujino } \\
\text { et al. }\end{array}$ & Diagnosis and Treatment & $\begin{array}{l}\text { Cost-benefit/cost-effectiveness analysis of pharmacother- } \\
\text { apy (magindol) and diet therapy in obesity }\end{array}$ \\
\hline 5 & 1993 & $\begin{array}{l}\text { Fujino } \\
\text { et al. }\end{array}$ & Clinical Report & $\begin{array}{l}\text { Cost-benefit/cost-effectiveness analysis of pharmaco- } \\
\text { therapy (misoprostol) for gastric ulcers associated with } \\
\text { NSAID treatment }\end{array}$ \\
\hline 6 & 1994 & $\begin{array}{l}\text { Imai } \\
\text { et al. }\end{array}$ & $\begin{array}{l}\text { Japanese Pharmacology \& } \\
\text { Therapeutics }\end{array}$ & $\begin{array}{l}\text { Pharmaco-economic effect of pimobendan therapy for } \\
\text { acute and chronic heart failure }\end{array}$ \\
\hline 7 & 1994 & $\begin{array}{l}\text { Fujino } \\
\text { et al. }\end{array}$ & $\begin{array}{l}\text { Journal of Clinical } \\
\text { Therapeutics \& Medicines }\end{array}$ & Socioeconomic evaluation of the effect of nicotine TTS \\
\hline 8 & 1994 & $\begin{array}{l}\text { Fujino } \\
\text { et al. }\end{array}$ & $\begin{array}{l}\text { Journal of Clinical } \\
\text { Therapeutics \& Medicines }\end{array}$ & $\begin{array}{l}\text { Socioeconomic evaluation of docarpamine-Cost minimi- } \\
\text { zation analysis based on a follow-up survey report on late } \\
\text { phase II and phase III clinical trials of docarpamine- }\end{array}$ \\
\hline 9 & 1994 & Kakihara & $\begin{array}{l}\text { Journal of Kyoto Prefectural } \\
\text { Univesity of Medicine }\end{array}$ & $\begin{array}{l}\text { Theoretical price model of pharmaceuticals by using a } \\
\text { method of health economics }\end{array}$ \\
\hline 10 & 1994 & $\begin{array}{l}\text { Fujino } \\
\text { et al. }\end{array}$ & $\begin{array}{l}\text { Journal of Clinical } \\
\text { Therapeutics \& Medicines }\end{array}$ & $\begin{array}{l}\text { Socioeconomic evaluations on drug trreatment for inflam- } \\
\text { matory bowel disease (IBD)-Effect of a controlled- } \\
\text { release mesalazine tablet (N-5ASA)- }\end{array}$ \\
\hline 11 & 1995 & $\begin{array}{l}\text { Fujino } \\
\text { et al. }\end{array}$ & $\begin{array}{l}\text { Journal of Clinical } \\
\text { Therapeutics \& Medicines }\end{array}$ & $\begin{array}{l}\text { Cost effectiveness analysis of pranlukast (Selective leu- } \\
\text { kotriene } \mathrm{C}_{4}, \mathrm{D}_{4}, \mathrm{E}_{4} \text { antagonist) in the bronchial asthma } \\
\text { therapy }\end{array}$ \\
\hline 12 & 1995 & $\begin{array}{l}\text { Ogawa } \\
\text { et al. }\end{array}$ & $\begin{array}{l}\text { Japanese Pharmacology \& } \\
\text { Therapeutics }\end{array}$ & $\begin{array}{l}\text { Cost effectiveness analysis of Sho-saiko-to therapy in the } \\
\text { liver cirrhosis }\end{array}$ \\
\hline 13 & 1995 & $\begin{array}{l}\text { Hisashige } \\
\text { et al. }\end{array}$ & Clinical Report & $\begin{array}{l}\text { Economic evaluation of disease modifying antirheumatic } \\
\text { drugs }\end{array}$ \\
\hline 14 & 1995 & $\begin{array}{l}\text { Hisashige } \\
\text { et al. }\end{array}$ & Diagnosis and Treatment & Economic evaluation of propofol \\
\hline
\end{tabular}

(2.1). 比較対照として設定されたのは臨床試験に おける対照薬やそれに準ずる既存治療である。こ のなかにはプラセボ投与を比較対照として用いた 2 文献が含まれていた。

3 ）治療の効果を確認した証拠があるか.

適応率：100\%（100\%）

対象文献は新薬あるいはそれに準ずる薬剤の経 済評価であり，このためすべての例で臨床試験が 行われていた（3.1）。また，分析の主たるデー夕
も臨床試験の結果に基づいていた.

4 ）それぞれの代替案について，重要かつ密接 に関連する費用と結果をすべて明らかにして いるか.

適応率： $50.0 \%(14.3 \%)$

費用項目はすべての文献で直接費用が用いられ ていたが，間接費用に言及していたのは 6 文献で あった (4.1). 結果や便益として, 費用・効果分 析では患者数, 生存年数, 症状軽快の点数, 入院 
Table 3 Results of quality review (1)

\begin{tabular}{|c|c|c|c|c|c|c|c|c|c|c|}
\hline \multirow{2}{*}{$\begin{array}{l}\text { Reference } \\
\text { no }\end{array}$} & \multicolumn{10}{|c|}{ Check list } \\
\hline & 1 & 2 & 3 & 4 & 5 & 6 & 7 & 8 & 9 & 10 \\
\hline 1 & $\triangle$ & $\triangle$ & $\bigcirc$ & $\times$ & $\triangle$ & $\triangle$ & $\bigcirc$ & - & $\times$ & $\triangle$ \\
\hline 2 & $\triangle$ & $\triangle$ & 0 & $\triangle$ & 0 & 0 & $\triangle$ & $\bigcirc$ & $\times$ & $\triangle$ \\
\hline 3 & $\triangle$ & 0 & $\bigcirc$ & $x$ & $\triangle$ & $\triangle$ & $\triangle$ & $\bigcirc$ & $\times$ & $\triangle$ \\
\hline 4 & $\triangle$ & $\triangle$ & $\bigcirc$ & $x$ & 0 & $\triangle$ & $\triangle$ & $\triangle$ & $\bigcirc$ & $\triangle$ \\
\hline 5 & $\triangle$ & $\bigcirc$ & $\bigcirc$ & $\times$ & $\bigcirc$ & $\triangle$ & $\triangle$ & $\bigcirc$ & $\times$ & $\triangle$ \\
\hline 6 & $\times$ & $\bigcirc$ & $\bigcirc$ & $\triangle$ & $\triangle$ & $\triangle$ & $\triangle$ & - & $\triangle$ & $\triangle$ \\
\hline 7 & $\triangle$ & $\triangle$ & $\bigcirc$ & $\times$ & 0 & $\bigcirc$ & $\triangle$ & 0 & $\bigcirc$ & $\triangle$ \\
\hline 8 & $\triangle$ & $\bigcirc$ & 0 & $\triangle$ & $\bigcirc$ & $\bigcirc$ & - & - & 0 & $\triangle$ \\
\hline 9 & $\triangle$ & $\triangle$ & $\bigcirc$ & $\times$ & $\times$ & $\triangle$ & $\times$ & - & $\bigcirc$ & $\triangle$ \\
\hline 10 & $\times$ & $\bigcirc$ & $\bigcirc$ & $\times$ & 0 & $\triangle$ & $x$ & 0 & $\bigcirc$ & $\triangle$ \\
\hline 11 & $\triangle$ & $\triangle$ & $\bigcirc$ & $\triangle$ & $\triangle$ & $\triangle$ & - & 0 & 0 & $\triangle$ \\
\hline 12 & $\triangle$ & 0 & 0 & $\triangle$ & 0 & $\triangle$ & $\triangle$ & 0 & 0 & $\triangle$ \\
\hline 13 & $\bigcirc$ & 0 & 0 & 0 & $\triangle$ & $\bigcirc$ & - & $\bigcirc$ & $\triangle$ & $\triangle$ \\
\hline 14 & 0 & $\bigcirc$ & $\bigcirc$ & 0 & $\bigcirc$ & 0 & - & - & $\bigcirc$ & 0 \\
\hline
\end{tabular}

期間，費用・便益分析では間接費用とともに医療 費削減効果が用いられていた。

しかし副作用は経済評価への影響が少ないとい う理由から無視されていた。また長期にわたる治 療が必要な慢性疾患での薬剂のコンプライアンス には言及されていなかった。

5 ）費用と結果を，適切な物理的単位で正確に 測定しているか.

適応率：92.9\%（57.1\%）

対象文献では，関連する費用と結果を比較的明 確に示していた（5.1）。しかし，なかには現状を 的確に反映していないモデルもみられた.

評価が長期にわたる場合，臨床試験からは十分 なデー夕を得ることができないため，データの一 部は他の疫学データから引用していた.たとえば, 対象文献 5 では misoprostol の臨床試験デー夕か
ら得られない胃潰瘍手術率を既存の研究報告から 引用し，モデルの一部に組みいれている。臨床試 験の限界を踏まえたうえでモデルを構築するには 他の疫学デー夕を用いることはやむをえないが, その際に使用する疫学デー夕の妥当性の吟味も必 要である。

6 ）費用と結果の価值づけは信頼できる方法で 行われているか

適応率：100\%（35.7\%）

対象文献では分析の方法を明確に表示していた (6.4). 分析手法は費用最小化分析 5 文献, 費用・ 効果分析 7 文献, 費用 - 便益分析 3 文献, 費用分 析 1 文献であった. 費用・効用分析はなかった. 3 文献では 2 つ方法により分析が行われてい た。しかし，著者が提示した方法と実際の分析方 法が相違したものが 8 文献もみられた。この点は 


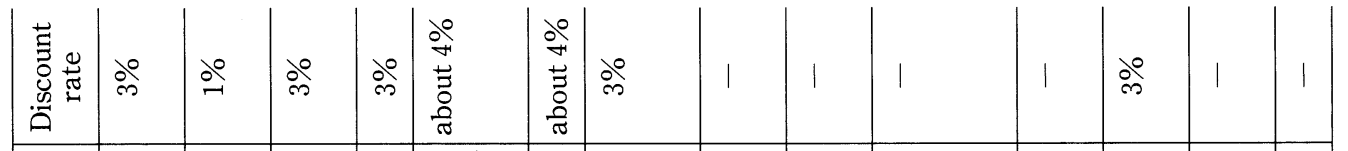

\begin{tabular}{|c|c|c|c|c|c|c|c|c|c|c|c|c|c|c|}
\hline 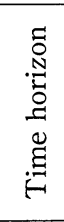 & 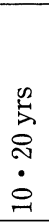 & $\stackrel{5}{5}$ & 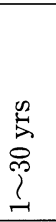 & 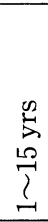 & 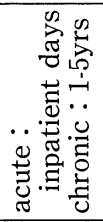 & $\begin{array}{l}5 \\
5 \\
5 \\
\stackrel{p}{2}\end{array}$ & $\begin{array}{l}\frac{0}{2} \\
5 \\
\frac{5}{2} \\
\frac{1}{2}\end{array}$ & 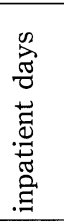 & 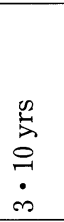 & $\begin{array}{l}\text { 尖 } \\
0 \\
\stackrel{1}{2}\end{array}$ & $\underset{H}{B}$ & 告 & $\begin{array}{l}B \\
\text { N }\end{array}$ & 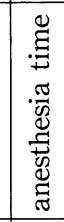 \\
\hline 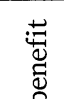 & & & 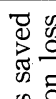 & & & & 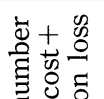 & & & $\stackrel{\infty}{a}$ & & 资 & & \\
\hline
\end{tabular}

\begin{tabular}{|c|c|c|c|c|c|c|c|c|c|c|c|c|c|c|}
\hline 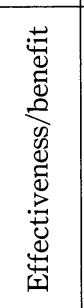 & 1 & 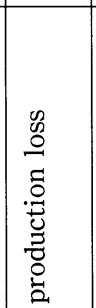 & 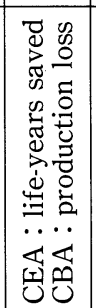 & 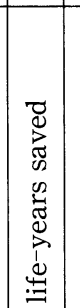 & 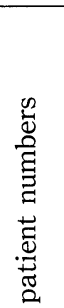 & 1 & 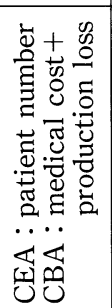 & 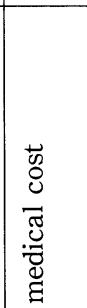 & 1 & 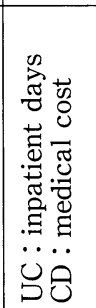 & 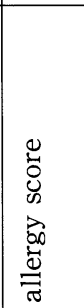 & 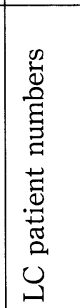 & 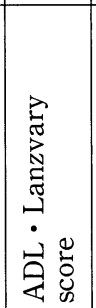 & 1 \\
\hline & 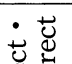 & 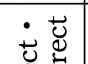 & $\dot{\vec{u}}$ & & & & & $\dot{U} \dot{u}$ & & & $\dot{u} \vec{u}$ & & & \\
\hline
\end{tabular}

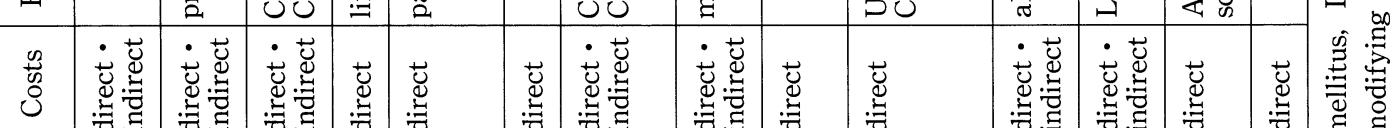

\begin{tabular}{|c|c|c|c|c|c|c|c|c|c|c|c|c|c|c|c|}
\hline & : & : & : & : & 足 & 弟 & 号: & 跑: & 莺 & 氙 & 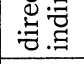 & פ⿹ & 苋 & : & \\
\hline 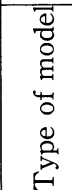 & 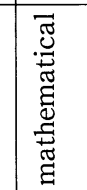 & 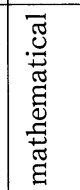 & 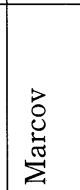 & 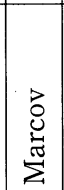 & 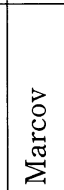 & 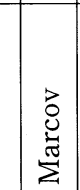 & 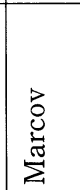 & 1 & 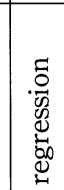 & 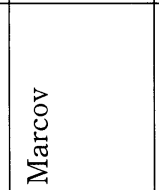 & 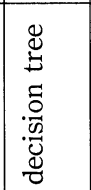 & 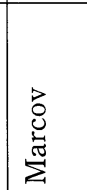 & 1 & 1 & \\
\hline 14 & & & & & & & & & & .. & & & & & \\
\hline
\end{tabular}

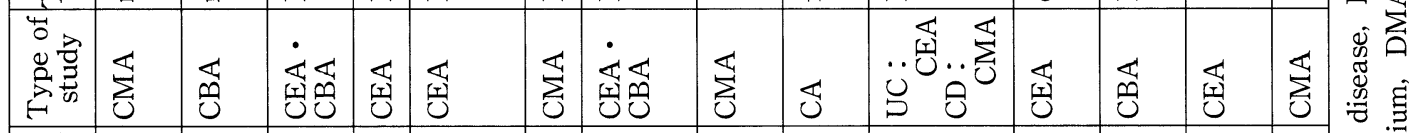

\begin{tabular}{|c|c|c|c|c|c|c|c|c|c|c|c|c|c|c|}
\hline & & & & & & 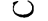 & & 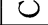 & 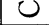 & & 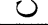 & 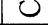 & 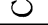 & \\
\hline 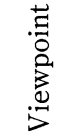 & r. & a. & r. & a. & r. & r. & r. & $a$. & $a$. & a. & $a$ & $a$. & 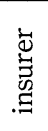 & 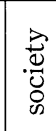 \\
\hline
\end{tabular}

\begin{tabular}{|c|c|c|c|c|c|c|c|c|c|c|c|c|c|c|c|}
\hline 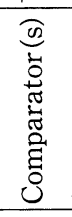 & 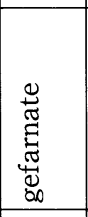 & 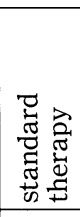 & 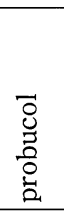 & 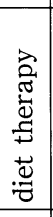 & 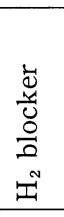 & $\mid \begin{array}{c}0 \\
\frac{8}{4} \\
\frac{\pi}{2} \\
\end{array}$ & 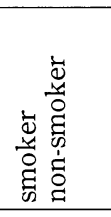 & 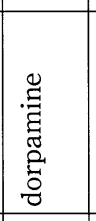 & 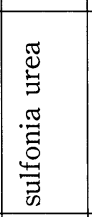 & 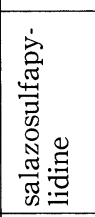 & \begin{tabular}{|l}
0 \\
$\frac{8}{\mathbb{Z}}$ \\
$\frac{\pi}{2}$ \\
2
\end{tabular} & 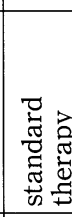 & 范啇 & 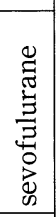 & 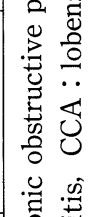 \\
\hline 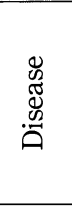 & 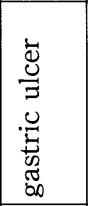 & 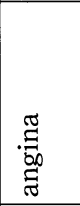 & 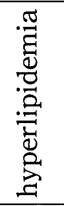 & $\begin{array}{l}\overrightarrow{3} \\
\vec{w} \\
-0 \\
0\end{array}$ & 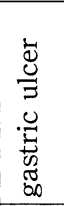 & 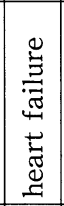 & 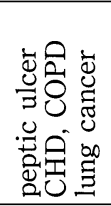 & 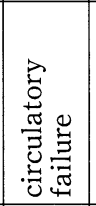 & 层 & 苗 & 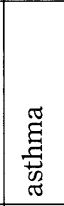 & u్ & 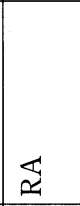 & 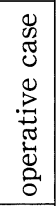 & 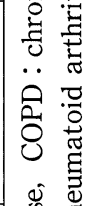 \\
\hline$\stackrel{\infty}{D_{2}}$ & 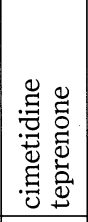 & 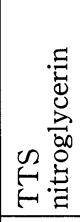 & 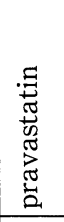 & $\begin{array}{l}\overrightarrow{\overline{0}} \\
\vec{g} \\
\vec{g} \\
\vec{g} \\
\vec{g}\end{array}$ & 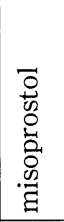 & 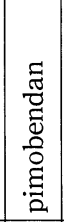 & 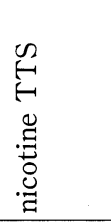 & 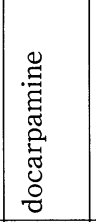 & 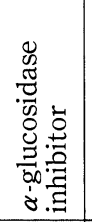 & 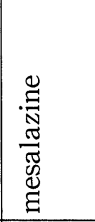 & 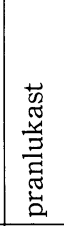 & 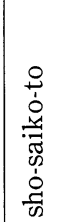 & 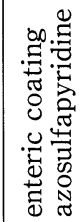 & 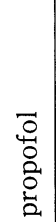 & 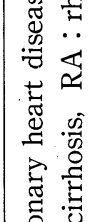 \\
\hline 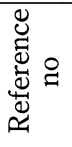 & -7 & $\sim$ & $\infty$ & $\theta$ & Lo & 0 & $n$ & $\infty$ & $\sigma$ & 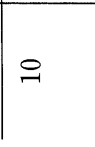 & $\exists$ & $\cong$ & $\stackrel{9}{9}$ & $\mathbb{Z}$ & 息 \\
\hline
\end{tabular}


薬剤疫学 Jpn J Pharmacoepidemiol, 2(2) Oct 1997 : 97

チェックリストの項目にはないが，分析方法の提 示が不十分と判断した。

7 ）費用と結果について，時期の違いを調整し ているか.

適応率 : $80 \%(10.0 \%)$

時間範囲は最短は麻酔時間であり, そのほかは 4 週から, 40 年に及んでいた。時間範囲が 1 年以 内の研究 (4 文献) は時間割引の必要はないと考え られるため, 現在価值への換算が求められるのは 10 文献であった (7.1)。このうち割引率が費用に 適用されていたのが 7 文献, 結果に適用されてい た 4 文献であった. なお, 結果に適用されていた 4 文献はすべて費用・便益分析であった。

適用した割引率は $3 \%$ が最も多かった。しかし 割引率の設定根拠を明確に示したのは 1 文献のみ であった (7.2).

8 ）代替案について, 費用と結果の増分分析を 行っているか

適応率：100\% (90.0\%)

費用最小化分析の 4 文献と費用分析 1 文献を除 く9文献に増分分析の必要性を認めた (8.1).こ れらはすべて増分分析が行われており，増分費用 とその結果追加された効果を比較検討していた。

9 ) 感度分析を行っているか.

適応率： $71.4 \%(57.1 \%)$

感度分析は 10 文献で行われ, その項目としては 麻酔時間，入院期間などが用いられていた (9.1). なお，薬剤費による感度分析のみを行っている 2 文献は不完全なものと判定した。このほか, 閾値 分析を行っているものが 2 文献あった.

10）研究結果の提示と考察は利用者にとって重 要な問題を含んでいるか.

適応率：100\%（7.1\%）

対象文献の結論は分析結果に基づいていた (10.1). しかし分析結果に基づいた考察は十分で はない場合が多く(10.2), 臨床上の問題点や政策 決定への利用までは必ずしも言及していなかっ た.このため研究結果を臨床に反映させるという 基本的姿勢を欠く傾向にあった.

また分析の限界，とくにモデルや分析に用いた データの妥当性について明確に述べていたのは 2
文献に留まった (10.3)。

\section{考察}

医療費の高騰に伴い, 医療の経済的側面をめぐ る諸問題が論議されている。このなかで医療技術 の経済的評価の推進も重要な課題と認識され, 平 成 9 年版厚生白書でもその必要性が述べられてい $3^{24)}$. 医薬品の経済評価は 1992 年 8 月より新薬の 薬価基準申請に医療経済評価資料の提出が認めら れ，薬価収載時の参考資料とされている。このた め経済評価に関する製薬企業の研究体制および行 政側の利用体制も整備されつつあると考えられ

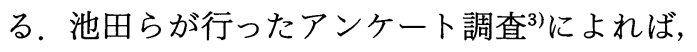
1992 年 8 月から 1995 年 12 月まで薬価収載され た医薬品は対象 22 社で 75 成分あり，このうち 54 成分 $(72 \%)$ に経済評価資料が提出されていた. そこで今回, 1985 年から 1995 年にわたり行政側 への提出を目的として行われたと考えられる医薬 品の経済評価研究について批判的吟味を行い, 今 後の医薬品経済評価の在り方を検討した.

\section{1. 対象文献の検討}

医薬品や医療技術の経済評価研究の批判的吟味 は, 欧米では研究テーマとしてたびたび取り上げ

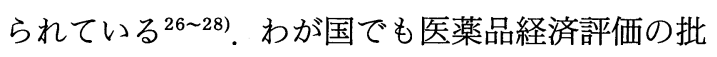
判的吟味には Moriga らの研究がある4)が, 対象文 献には既存薬も含まれているため, 有効性の検証 を欠いていたり, 食道静脈瘤硬化療法など特定の 薬剤を対象としない文献も含まれている。 そこで, 我々は新薬承認に際し前提となる臨床試験により 有効性が検証された薬剤を中心に評価を行った。

対象文献として抽出されたのは 11 年間で 14 文 献にすぎず, このうち 1992 年以降に発表されたの が 11 文献であった。ただし，このなかには新規収 載された真の新薬ではなく, 剂型追加例や保険適 応とされていない nicotine TTSも含まれてい る. 新薬は今回分析の対象となった cimetidine が 承認された 1981 年から, propofol, pranlukast が 承認された 1995 年まで 524 成分が認可を受けて いる。これら新薬の経済評価は公表論文は $1.7 \%$ にすぎず，他の新薬で経済性が考慮されていたか については判断材料がない. 
医薬品経済評価の必要性が十分に認められない 状況では, 資料の不足が医薬品経済評価研究の質 に影響したことも否めない.この点を加味すれば, 今回の検討で基本的条件を欠いていた点はやむを えない部分もあると思われる。今回の対象文献を みても医薬品経済評価の研究者もわずかながらも 増加し, 年代を経るごとに徐々に研究の質も高ま りつつある。今後は経済評価の必要性が再認識さ れ, 薬価への反映や臨床判断への利用を見据えた 質の高い研究が求められると考えられる.

\section{2. 対象文献の批判的吟味}

新薬承認を目的とした臨床試験のデータは内的 妥当性が高く, 経済評価に有用なデー夕を得るこ とが可能となる. しかし臨床試験のデータを用い た経済評価でも，それ以外に種々の問題点があり， 厳密な意味ではチェックリストを満たすものは 45.8\%にすぎなかった.そこで 14 文献に共通する 問題点を以下にまとめた.

\section{1) 分析方法}

対象文献として，いずれも経済評価が明確に行 われているものを抽出の原則とした。にもかかわ らず，対象文献中で提示されていた方法と論文中 で行われた方法が一致しない例や不十分な例が存 在した。たとえば，対象文献 9 で著者の示した経 済評価の方法は費用・効果分析だが，実際に行わ れたのは費用分析であった。このように著者が提 示した方法と実際の分析方法が相違したものが 8 文献もみられた。これらの文献に共通する問題点 は, 経済評価の方法や分析の立場が曖昧であった り，明確にされていないことであった，経済評価 を行うには, 分析方法を明確にし, その原則に従っ た検討を行うべきである。

2 ）モデルの妥当性

臨床試験のデー夕は内的妥当性は高いが, 長期 にわたるデータが得られるわけではなく, 効果指 標もいわゆる surrogate endpoint であることが 多い. 経済評価を行う場合, 最終的指標を用いる ことが望ましいが, 臨床試験においてはそのよう なデー夕はほとんど得られない.このため, 既存 薬におけるデー夕や他の疫学デー夕を用いたモデ ルによる推定に頼らざるをえない場合が多い.
今回検討した文献では，実際の臨床例とはかけ はなれ現実性に欠けたモデルを用いているものも 少なからず見受けられた.たとえば, 対象文献 1 の モデルでは胃・十二指腸潰瘍が 6 回の再発により 手術適応になるモデルが構築されている. しかし 胃・十二指腸潰場の手術適応は再発の回数に規定 されるのではなく，出血や穿孔などの不測の事態 によることが多い. このようにモデルは分析結果 に影響し，その信頼性も左右する。 モデル構築は， 疫学デー夕に基づいた上で, 臨床医との共同作業 として進めるのが望ましいと考えられる.

\section{3 ）分析の立場}

分析の立場については明示されていないものが 大半であった，基本となる分析の立場が不明確な 点は欧米の経済評価研究でも指摘されている. Udvarhelyi の行った同様の研究 ${ }^{26)}$ で分析の立 場を明確にしたものは $18 \%$ にすぎなかった。

経済評価における分析の立場としては一般に社 会的立場が望ましいとされる ${ }^{6)}$. 分析の立場によ りとらえるべき費用や健康結果が異なる場合もあ り，わが国における今後の経済評価を行う際に明 確にすべき点である。

\section{4 ）代替案の設定}

代替案の設定は臨床試験での対照治療が用いら れていた。 しかし今回の対象文献ではプラセボ投 与による治療を対照としたものが 2 例あった.

経済評価の分析結果の臨床判断への応用という 観点からみれば，代替案としてプラセボ投与によ る治療を用いることは望ましいとはいえない。実 際の臨床の現場では通常, 既存薬による治療が行 われており, 汎用されている既存薬との比較対照 をもって，本来の健康結果を測定することが望ま しい28). しかし, 既存薬のデー夕については, 治験 実施時の企業間の契約上の問題から利用が許され ない場合もある。経済評価の質の向上のためには こうした制約を取り払い，研究を円滑に進めるた めの合意形成を進めるべきである。

5 ) 割引率

割引率は時間範囲との関連で， 1 年以上に及ぶ ものには適応している場合が大半であった.一方, 欧米の研究では 14〜30\%のみに行われているに 
薬剤疫学 Jpn J Pharmacoepidemiol, 2(2) Oct 1997：99

すぎず25,26)，この点についてはわが国の研究も評 価できる.

しかし, 割引率を用いる際の根拠は 1 文献を除 き明確ではなく，1\%から $4 \%$ までばらつきがみら れた。欧米では割引率として $5 \%$ が用いられるこ とが多く,わが国独自の割引率を設定する場合は 選択した值を正当化する必要があると考えられ る.

\section{6 ）感度分析}

対象文献 14 文献中 10 文献に行われており，行 われていない例は比較的初期の研究であった。感 度分析は経済評価の結果の頑健性 (robustness) を 検証するため行われる。感度分析は, 欧米の研究 においても 6〜 48\% ${ }^{25,26)}$ と十分には行われてはい ない.しかしながら, 臨床試験によりすべてのデー 夕を得られるとは限らず, また疫学データも完備 されていない状況では，不確定な值について必ず 行われるべきである。

感度分析は比較的良好に行われてはいるが，感 度分析の項目の適切性にも問題がある. 2 文献は 新薬の薬価が定まらないことを事由として, 薬剤 費による感度分析を行っていた。しかし，薬剤費 の感度分析はシナリオ設定の変更にすぎず，感度 分析の目的である不確定性の高い要因について結 果の頑健性を検討しているわけではない.この観 点から，今回は薬剤費による感度分析を行った例 は，厳密にはチェックリストには十分適応しない ものとした。

7 ）医薬品経済評価の臨床への利用

医薬品経済評価を行う場合, 経済学者による分 析では臨床上の問題点が適切に把握されない可能 性があり，分析結果を臨床に応用することが困難 な場合がある。このため, 経済評価のための経済 評価にしかならず，医療従事者からみれば現実と 乘離したものとしか受け止めらない可能性があ る。医療従事者の関心を喚起するには, 臨床の現 場に経済評価がどのような問題を提起し，解決の 糸口を見い出せるかについて提示する必要があ る。経済評価は必ずしも臨床とかけはなれたもの ではなく, 分析方法や結果の提示方法次第で, 臨 床判断や政策決定に応用可能である。こうした認
識のもとで，モデルの構築やデータの収集に際し て医療従事者や疫学者らの協力が十分に得られる 状況になれば，経済評価の質をさらに高めること が可能となろう。

\section{3. 医薬品経済評価の問題点と今後の展望}

これまで医薬品経済評価はその必要性が十分認 識されず，分析のための資料不足をはじめとして 環境が整っていなかった。たとえば対象文献の発 表誌をみても学会誌はわずか 1 誌にすぎず，これ までの状況では経済評価研究を受け入れる基盤そ のものを欠いていた．医薬品経済評価を原著論文 として受け入れる場が非常に限られていること, またそれだけに研究結果が臨床に反映されないこ とが問題点の 1 つに上げられる. 確かに医薬品経 済評価の方法や利用には未解決の課題もあるが, 公の場で討論され吟味し, 互いの研究の質を高め ることが可能である。 また医薬品経済評価の成果 を利用することは, 医薬品の適正な使用を促し, 医療の質の向上にも役立つものと考えられる.

医薬品経済評価の研究の質を高めるためには, 疫学データの集積が必要であることはたびたび指 摘されている。しかし疫学データの集積は長期に わたり積み重ねられ結実するものであり, この点 は地域癌登録をもとに癌対策の評価が行われるま で長い歳月を要した事実からも推測される。種々 の学会などで行われている諸統計も経済評価にそ のまま使用できないこともあり，こうした点は臨 床医の意識を改善し, 応用可能なデー夕集積が行 われることが期待される。もちろん経済評価が容 易に行えない原因を単にデータの不足に帰するべ きではなく, 臨床試験施行時には経済評価を見据 えたデータの収集・蓄積を行うことが現実的な場 合もある.

医薬品経済評価を行ううえで現在の状況を改善 するには, 諸外国で提示されている医薬品経済評 価研究のガイドラインが参考となる ${ }^{1)}$.これらの ガイドラインは医療費抑制の目的だけではなく， 保険償還可否の判断や価格決定など政策的意図を もって作成されている，わが国でもこうしたガイ ドラインを作成することにより, 医薬品経済評価 の役割を明確にし，医療従事者にも経済評価を理 
解し応用するうえ上での指針となる.

医薬品の経済評価はわが国においても関心が高 まりつつある，今後の発展のためには，医薬品経 済評価ガイドラインの作成や疫学データの集積に 加え, 医療従事者への啓蒙, 疫学者との研究協力, 薬剤疫学の専門家の育成などの整備が必要と考え られる。こうした環境整備に基づき医薬品経済評 価が質を高めることにより，ひいては医療全体の 向上に寄与するものと期待される.

\section{結＼cjkstart論}

日本における医薬品経済評価の文献の批判的吟 味を行い，その結果に基づき考察した。対象文献 は分析の立場が不明確であり，モデルの妥当性の 検証を欠く傾向がみられた。 また経済評価の結果 に基づいた臨床への応用の可能性などの考察を欠 いていた。 今後は医薬品経済評価のガイドライン の作成とともに，臨床試験施行時には経済評価を 見据えたデー夕の収集・蓄積が今後の課題と考え られた。

\section{文献}

1）池田俊也．医薬品経済評価の手法の標準化に関する 研究. 病院管理 $1996 ； 33(3) ： 43-8$.

2）厚生省保険局医療課監修．欧米諸国における薬剤と 医療保険制度改革．薬業時報社，1995：157.

3）池田俊也，井上晋. 製薬企業に扔ける医薬品経済評 価の現状と政策決定への利用. 社会保険旬報 $1996 ; 1924: 24-6$.

4) Moriga M, Ikeda S, Reich MR. An analysis of pharmacoeconomics studies in Japan. 医療経済研究 $1995 ； 2 ： 73-83$.

5) Ikeda S, Noguchi N, Oliver AJ, Ikegami N. A review of pharmacoeconomic study in Japan. Clin Ther $1996 ; 18$ supple A : 39 .

6) Drummond MF, Stoddart GL, Torrance GW. Methods for the economic evaluation of health care programmes. Oxford: Oxford medical publications, $1987: 18-39$.

7) Detsky AS. Guideline for economic analysis of pharmaceptual products : a draft document for Ontario and Canada. Pharmaco Economics 1993 ; 3:354-61.

8) Sacristan JA, Soto J, Galende I. Evaluation pharmacoeconomic studies : utilization of a checklist. Ann Phar 1993；27：1126-33.

9）久繁哲徳, 西村周三監訳. 臨床経済学一医療 - 保健
の経済的評価とその方法一。篠原出版, 1990：44-6.

10) Fujino S, Suzuki $Y$, Tanaka T. Cost-benefit analysis of medical treatment for gastric ulcers. Long-term model including healing and reccurrence. Health Policy $1985 ; 5: 45-72$.

11）藤野志朗, 佐藤貴一郎, 今井英彦, 赤澤とし子. TTS ニトログリセリンのコスト・ベネフィット分析一新 しいデリバリ・システムのテクノロジー・アセスメ ント・モデルー。薬理と治療 $1988 ； 16(12) ： 267-$ 302.

12）藤野志朗，鈴木雪夫，佐藤貴一郎，今井英彦，赤澤 とし子．冠動脈疾患に対する高脂血症治療剤のコス ト・エフェクテイブネス分析一プラバスタチン (HMG-CoA 還元酵素阻害剂) に上る薬物療法の効 果一。臨床医薬 $1989 ； \mathbf{5}(3): 461-90$.

13）藤野志朗, 斎藤康, 佐藤貴一郎, 今井英彦, 赤澤と し子. 肥満症治療に扔ける食事療法と薬物療法（マ ジトール）のコスト・ベネフィット/コスト・エフェ クテイブネス分析．診療と新薬 $1992 ； 29(4) ： 183-$ 202.

14）藤野志朗，塩川祐一，今井英彦ら。非ステロイド性 消炎鎮痛剤投与時にみられる胃潰瘍における薬物療 法（ミソプロストール）のコスト・ベネフィット/コ スト・エフェクテイブネス分析．基礎と臨床 1993 ； 27(6) : 2523-39.

15）今井英彦, 清野精彦, 早川弘一, 藤野志朗, 赤澤と し子、急性および慢性心不全に対するピモベンダン 療法の経済効果。薬理と治療 $1994 ； 22(7) ： 383-$ 94.

16）藤野志朗，佐藤貴一郎，今井英彦，赤澤とし子，小 川京子. ニコチン TTS の社会計学的効果の分析. 臨床医薬 $1994 ； 10(7) ： 1477-92$.

17）藤野志朗，今井英彦，赤澤とし子．ドカルパミンの 社会経済的評価一ドカルパミン後期第 II 相試験・第 III相試験の追跡調查研究報告に基づく費用最小化分 析一。臨床医薬 $1994 ； 10(9): 1973-91$.

18）柿原浩明. 医療経済学的分析手法を用いた理論薬価 モデル一新しい糖尿病薬の開発に関連して一。 京府医大誌 $1994 ； 103(4) ： 475-85$.

19）藤野志朗，樋渡信夫，佐藤貴一郎，今井英彦，赤澤 とし子, 小川京子. 炎症性腸疾患 (IBD) の薬物療法 に関する社会経済的評価一メサラジン経口放出制御 骭 $(\mathrm{N}-5$ ASA) の効果一。臨床医薬 $1995 ； 11(7)$ : $1357-79$.

20）藤野志朗，佐藤貴一郎，今井英彦，赤澤とし子，小 川京子．抗喘息薬プランルカスト（選択的ロイコト リエン C 4, D 4, E 4 拮抗薬) のコスト・エフェクテ イブネス分析. 臨床医薬 $1995 ； 11(11) ： 2303-23$.

21）小川京子, 岡博子, 藤野志朗. 肝硬変における小柴 胡湯のコスト・エフェクテイブネス分析. 薬理と治療 $1995 ； 23(8) ： 57-65$.

22）久繁哲徳, 片山貴文, 三笠洋明. 疾患修飾性抗りウ マチ薬の経済評価。基礎と臨床 $1995 ； 29(17) ：$ 4557-70. 
薬剤疫学 Jpn J Pharmacoepidemiol, 2(2) Oct 1997：101

23）久繁哲徳, 真下節, Drummond MF. 静脈麻酔薬プ ロポフォールの経済評価一費用最小化分析（CostMinimization Analysis)一。診断と治療 1995 ; 83(9) : 1659-65.

24）厚生省編. 平成 9 年度厚生白書「健康」と「生活の 質」の向上をめざして. $1997 ； 138-41$.

25) Lee JT, Sanchez LA. Interpretation of "costeffective" and soundness of economic evaluations in the pharmacy literature. Am J Pharm 1991; 48:2622-7.

26) Udvarhelyi IS, Colditz GA, Epstein AM. Costeffectriveness and cost-benefit analysis in the medical literature-Are the methods being used correctly?-. Ann Intern Med 1992 ; 116(3) : 238
-43 .

27) Bradey CA, Iskedjian $M$, Lancotot $\mathrm{KL}$, et al. Quality assessment of economic evalutions in selected pharmacy, medical, and health economical jounals. Ann Pharmacother 1995 ; 29 ; 681-9.

28) Drummond MF. Jefferson TO. Guidelines for authors and peer reviewers of economic submissions to BMJ. BMJ $1996 ; 313: 275-83$.

投稿受付： 1997 年 8 月 4 日 第 2 稿受付：1997 年 8 月 18 日 掲載決定：1997 年 9 月 12 日 